Kumawula, Vol. 3, No.3, Desember 2020, Hal 469 - 476 DOI: https://doi.org/10.24198/kumawula.v3i3.28953

ISSN 2620-844X (online)

Tersedia online di http://jurnal.unpad.ac.id/kumawula/index

\title{
PENINGKATAN IDE KREATIF DAN INOVATIF PADA DESAIN PRODUK HASIL OLAHAN DESA PAMULIHAN, KABUPATEN SUMEDANG
}

\author{
Vita Sarasi ${ }^{*}$, Hilmiana ${ }^{2}$, M. Aqshel Revinzky ${ }^{3}$ \\ ${ }^{1}$ Departemen Manajemen, Fakultas Ekonomi dan Bisnis, Universitas Padjadjaran \\ ${ }^{2}$ Departemen Manajemen, Fakultas Ekonomi dan Bisnis, Universitas Padjadjaran \\ ${ }^{3}$ Departemen Manajemen, Fakultas Ekonomi dan Bisnis, Universitas Padjadjaran
}

*Korespondensi : vita.sarasi@unpad.ac.id

\begin{abstract}
ABSTRAK
Universitas Padjadjaran melakukan pengabdian kepada masyarakat pada tahun 2020 melalui program Kuliah Kerja Nyata Tematik Kewirausahaan (KKN KWU). Pengabdian kepada masyarakat ini salah satunya dilakukan di Desa Pamulihan yang memiliki banyak potensi dalam bidang kewirausahaan. Berdasarkan analisis kebutuhan, didapatkan berbagai permasalahan pada wirausahawan Desa Pamulihan, yaitu tentang inovasi dan kreativitas pemasaran produknya, misalnya kemasan produk. Dengan gambaran permasalahan tersebut, tim KKN KWU Unpad melaksanakan Lokakarya Kewirausahaan dengan mengangkat berbagai tema tentang inovasi dan kreativitas pemasaran produk, yaitu tentang desain kemasan produk, pemasaran digital, motivasi kewirausahaan berkelanjutan, harga pokok produk, dan strategi marketing. Terdapat beberapa saran yang penulis ajukan berdasarkan evaluasi kegiatan ini, antara lain untuk melanjutkan kegiatan ini dengan pelatihan skill pembuatan kemasan produk, melibatkan lebih banyak peserta lagi, serta persiapan yang lebih matang.
\end{abstract}

Kata Kunci: Kewirausahaan, Inovasi, Desain Produk

\section{ABSTRACT}

Padjadjaran University serves its community in the year 2020 through the Real Work Lecture Program about Entrepreneurship (also known as Kuliah Kerja Nyata; KKN KWU). Pamulihan Village, one of places where this program was held, has a lot of potential in entrepreneurship. Based on the need analysis, various problems were found regarding innovation and creativity in marketing their products, including product packaging. Based on the problems found, KKN KWU Unpad team conducted an Entrepreneurship Workshop with various themes on product marketing innovation and creativity, namely on product packaging design, digital marketing, sustainable entrepreneurial motivation, product cost prices, and marketing strategies. There are several suggestions that the author proposes based on the evaluation of this program, including to continue this work by training skills in product packaging, involving more participants, and do a better preparation.

Keywords: Entrepreneurship, Innovation, Product Design

\section{PENDAHULUAN}

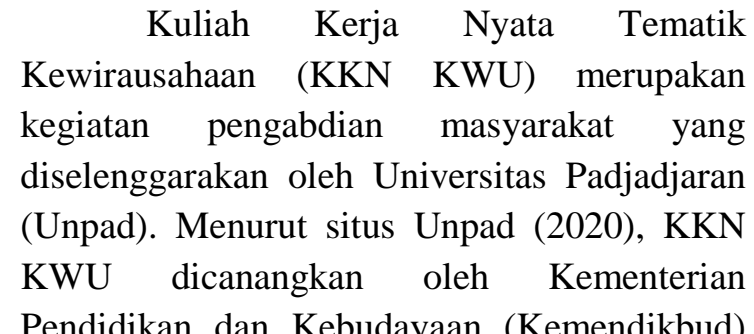

agar mendorong kampus untuk memberikan kebebasan kepada mahasiswa untuk belajar dengan lebih fleksibel. Kegiatan ini juga melibatkan dosen yang nantinya dapat mengaplikasikan risetnya langsung di lapangan agar mampu menghasilkan manfaat secara nyata. KKN KWU pada dasarnya merupakan kegiatan yang diselenggarakan untuk masyarakat dengan fokus pada tema kewirausahaan. Tujuannya adalah agar 
masyarakat bisa mengembangkan usahanya dengan lebih modern, efektif, dan inklusif. Selain itu, menurut Karlina, dkk. (2019), melalui KKN ini mahasiswa dapat mengembangkan kreativitasnya dalam membantu memberikan solusi atas permasalahan yang ada di masyarakat khususnya pada aspek kewirausahaan.

Salah satu desa yang menjadi target pelaksanaan KKN KWU tahun 2020 adalah Desa Pamulihan. Desa Pamulihan adalah desa yang berlokasi di wilayah Kecamatan Pamulihan, Kabupaten Sumedang, Provinsi Jawa Barat. Secara administratif, Desa Pamulihan terbagi ke dalam tiga dusun yaitu Dusun I, Dusun II, dan Dusun III, yang terbagi lagi ke dalam 9 RW dan 35 RT (Badan Pusat Statistik Sumedang, 2019).

Desa Pamulihan merupakan desa yang memiliki potensi besar dalam kewirausahaan. Menurut Hiliana, dkk. (2020), Desa Pamulihan merupakan desa yang diklasifikasikan sebagai desa swadaya. Dengan kata lain, desa ini mampu menghidupi dirinya sendiri. Desa Pamulihan memiliki berbagai sumber mata pencaharian di mana sebagian besar penduduknya bekerja di sektor pertanian dan penduduk lainnya bekerja di sektor perdagangan, sektor industri, atau menjadi Pegawai Negeri Sipil (PNS) atau TNI dan Polri. Terdapat berbagai hasil pertanian dari desa ini, misalnya talas, manggis, jambu, golden berry (cecanet), dan ubi yang kemudian dijual. Selain menjual hasil tani, Desa Pamulihan memiliki berbagai usaha kuliner, misalnya usaha penjualan tahu, ulen, ubi, cireng dan peuyeum. Desa ini juga mampu menghasilkan kerajinan tangan seperti pembuatan wayang, patung dan layang-layang yang nantinya dipasarkan. Bahkan, Desa Pamulihan pun memiliki potensi lain yang belum terlalu dikenal, yaitu pemberdayaan maggot sebagai pakan untuk peternakan.

Potensi yang besar memerlukan
penanganan yang sesuai agar bisa
dikembangkan secara efektif. Pada zaman
sekarang di mana persaingan sangat ketat,
dibutuhkan inovasi baru yang mampu

mengikuti perkembangan zaman. Inovasi produk menurut Hurley dan Hult (1998) (dikutip dalam Purnomo dan Purnomo, 2017) adalah sebuah mekanisme yang dijalankan perusahaan agar dapat beradaptasi dalam lingkungan yang dinamis. Menurut Rogers (2010), ciri-ciri inovasi adalah khas, baru, terencana, dan memiliki tujuan. Sebuah inovasi biasanya berisi terobosan-terobosan baru mengenai sebuah hal yang diteliti oleh sang inovator dan sengaja dibuat oleh sang inovator melalui berbagai macam aksi atau pun penelitian yang terencana. Menurut Stamm (2008), pembuatan inovasi ini juga tentunya memerlukan kreativitas yang tinggi.

Salah satu hal yang perlu ditingkatkan dari produk wirausaha Desa Pamulihan adalah inovasi produk pada desain produk hasil olahan Desa Pamulihan. Hal ini diketahui berdasarkan analisis kebutuhan yang dilakukan oleh penulis, di mana ditemukan bahwa hal yang belum dilakukan oleh warga Desa Pamulihan adalah bagaimana cara pengemasan dan pemasaran produk tersebut.

Terdapat beberapa contoh kasus di mana desain kemasan dapat meningkatkan pembelian produk. Kasus pertama adalah usaha wayang golek yang dijalankan oleh seorang pengusaha di Desa Pamulihan selama sepuluh tahun (Gambar 1). Menurut pengusaha yang memproduksi wayang golek tersebut, wayang golek yang telah dibuat kemudian didistribusikan ke daerah Cipacing. Jumlah wayang golek yang dipasarkan berkisar sekitar sepuluh buah per bulan, di mana penjualan setiap wayang goleknya berkisar antara enam ratus hingga delapan ratus ribu rupiah. Sayangnya, wayang golek yang dibuatnya tidak memiliki kemasan khusus. Akibatnya, walaupun wayang tersebut sudah dipasarkan ke berbagai kota, pulau, bahkan keluar negeri, para konsumen yang membeli tidak tahu bahwa produk tersebut diproduksi di Indonesia, khususnya di Desa Pamulihan. Dengan pemberian kemasan khusus, selain dapat menjadi sarana promosi bagi pengusaha Wayang Golek di Desa Pamulihan, juga menarik investor untuk membantu dari segi 
pemodalan. Biaya sebagai modal untuk membuat wayang inilah yang diakui oleh pengusaha wayang golek tersebut menjadi masalah yang dialaminya.
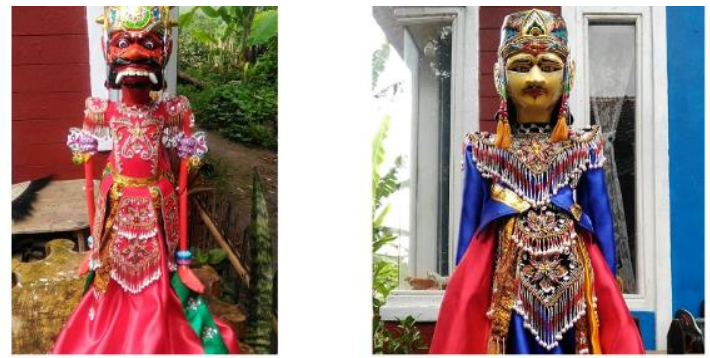

Gambar 1. Contoh wayang hasil produksi pengusaha wayang golek di Desa Pamulihan yang dipasarkan tanpa kemasan khusus (Sumber: dokumentasi pribadi, 2020)

Selain dari permasalahan tersebut, terdapat beberapa masalah lain yang dilaporkan oleh warga. Pertama, beberapa wirausahawan juga ingin tahu lebih mendalam tentang cara memasarkan suatu produk. Menurut warga setempat, mereka hanya memanfaatkan promosi berbentuk mouth-to-mouth promotion yang sudah tidak efektif dilakukan pada era digital ini. Contoh pemasaran produk dengan strategi ini adalah bisnis surabi yang dijalankan oleh sepasang suami istri (Gambar 2). Persiapan penjualan surabi dimulai dari jam 03.30 pagi dan pada jam 08.00 pagi surabi sudah habis terjual. Harga jual per buah untuk surabi original adalah seribu rupiah, untuk surabi oncom adalah seribu rupiah, serta surabi telur adalah empat ribu rupiah. Keuntungan per hari bisa mencapai dua ratus ribu rupiah. Akan tetapi, dengan strategi pemasaran produk seperti ini, dimana surabinya juga tidak dikemas secara khusus membuat penjualan harian yang ada hanya dapat memenuhi kebutuhan masyarakat di sekitar Desa Pamulihan saja. Jika kemasan surabi dibuat lebih menarik, maka ada peluang untuk dapat dijual di toko yang lebih besar bahkan dikirim ke desa lainnya.
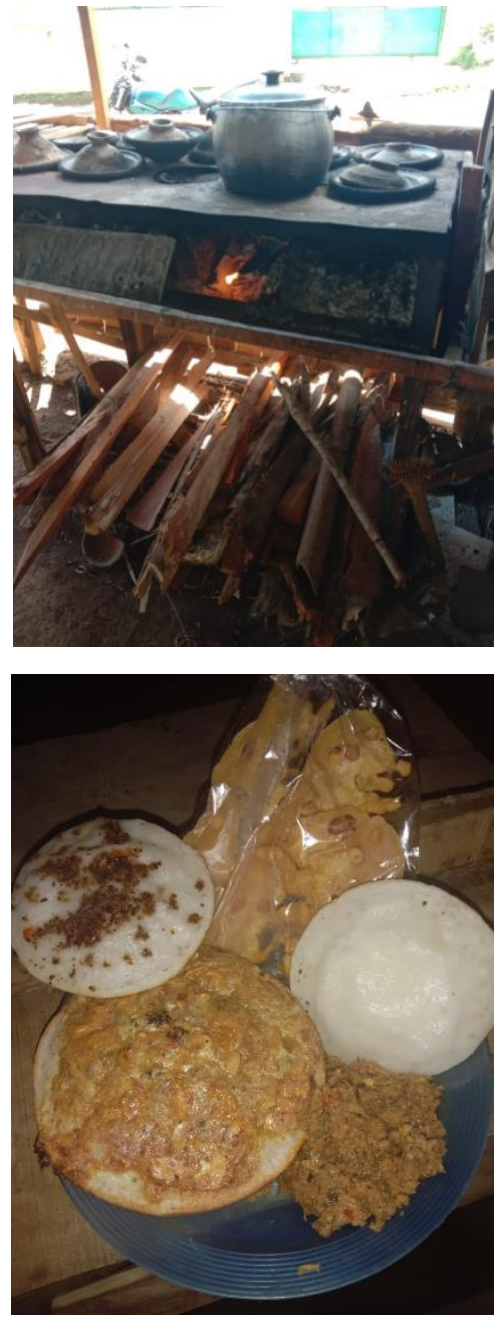

\section{Gambar 2. Usaha surabi yang dijalankan oleh salah satu pengusaha di Desa Pamulihan}

(Sumber: dokumentasi pribadi, 2020)

Kedua permasalahan tersebut juga dijumpai pada pengusaha lainnya, misalnya pada pengusaha Tahu Sumedang yang didatangi oleh tim KKN KWU Unpad (Gambar 3). Dalam satu hari tahu yang terjual bisa sampai tiga puluh wadah, di mana satu wadah berisi seratus hingga seratus dua puluh buah tahu. Harga jual per buah berkisar antara dua ratus lima puluh hingga empat ratus rupiah. Omset per bulan mencapai satu setengah juta rupiah. Setelah diproduksi, tahu ini kemudian dijual di daerah Kiaracondong, Bandung. Dengan membuat kemasan yang menarik, produk ini pun bisa dijual ke berbagai tempat. 


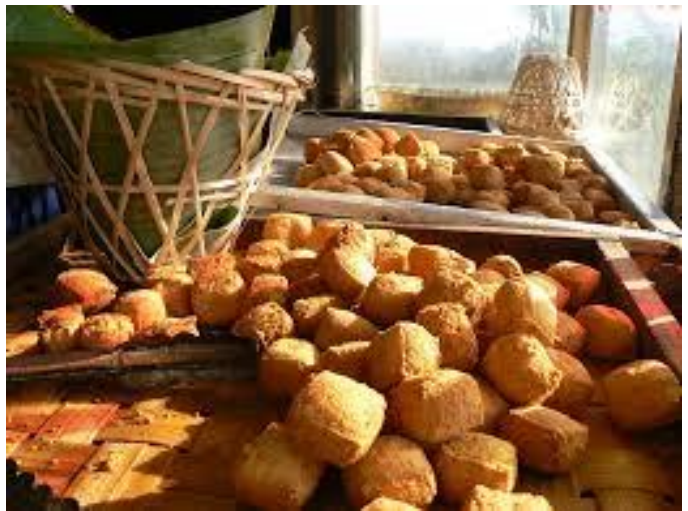

Gambar 3. Tahu Sumedang yang diproduksi di Desa Pamulihan tanpa kemasan khusus

(Sumber: dokumentasi pribadi, 2020)

Selain kedua permasalahan tersebut, ditemui pula bahwa hampir setiap wirausahawan merasa bingung mengenai regenerasi usaha yang sudah dirintis. Apabila diperhatikan, anak-anak muda Desa Pamulihan terlihat kurang tertarik untuk terjun langsung ke dalam bidang wirausaha. Karena permasalahan itulah, para wirausahawan saat ini cukup kuatir mengenai keberlanjutan dari usahanya masingmasing.

Melihat adanya gambaran permasalahan tersebut yang disertai dengan potensi tertentu, KKN KWU tahun 2020 ini bertujuan untuk meningkatkan pola berpikir kreatif masyarakat Desa Pamulihan agar produk yang dihasilkan dapat menarik para investor dan pada akhirnya dapat dipasarkan ke masyarakat yang lebih luas. Kegiatan ini memang secara khusus bermaksud untuk meningkatkan inovasi dalam pembuatan desain kemasan produk, namun juga bertujuan untuk memunculkan pola berpikir inovatif dan kreatif secara umum. Manfaat dari kegiatan ini adalah untuk meningkatkan taraf kehidupan masyarakat Desa Pamulihan dengan hasil produk yang memiliki desain produk yang inovatif.

\section{METODE}

Kegiatan KKN KWU ini dilakukan melalui beberapa tahap. Tahap pertama adalah familiarisasi, yaitu tahapan memperkenalkan dan mendekatkan diri pada masyarakat dan tokoh-tokoh desa, silaturahmi dengan masyarakat desa, tokoh desa dan wirausahawan.

Tahap selanjutnya adalah tahap identifikasi, yaitu tahapan mencari data dan informasi mengenai kondisi permasalahan dan potensi yang ada di Desa Pamulihan terutama dalam permasalahan kewirausahaan. Kegiatan yang dilakukan antara lain adalah mencari data relevan tentang Desa Pamulihan, membuat peta potensi, melakukan survei, dan mencari data wirausaha. Tahap ini juga mencakup analisis kebutuhan. Tahap identifikasi merupakan tahap yang penting karena hasil tahap ini akan digunakan untuk menetapkan tujuan kegiatan KKN KWU dan metode pelaksanaannya.

Berdasarkan penilaian kebutuhan yang dilakukan, ditemukan bahwa permasalahan yang dihadapi oleh para wirausahawan Desa Pamulihan adalah mengenai pengemasan suatu produk agar lebih menarik dan fungsional, tata cara melakukan pemasaran di era digital, penetapan harga pokok produk yang tepat, dan motivasi untuk tetap melakukan wirausaha. Melihat gambaran kebutuhan tersebut, tim KKN KWU menentukan bahwa metode yang paling sesuai yaitu dengan mengadakan lokakarya berbentuk seminar dan sesi tanya jawab yang berfungsi untuk menambah pengetahuan dan memberikan motivasi kepada warga desa. Program lokakarya tersebut dilakukan dengan tujuan agar dapat meningkatkan kesadaran dan kemampuan dalam memberdayakan potensi yang ada di Desa Pamulihan. Dengan adanya program lokakarya dan pelatihan kewirausahaan ini diharapkan masyarakat Desa Pamulihan dapat lebih berpikir kreatif dalam menjalankan usahanya di antaranya dalam mendesain produk hasil olahannya, proses pemasaran serta dalam mengembangkan usahanya.

Tahap ketiga adalah implementasi dari tahap identifikasi, yaitu berpartisipasi langsung dalam kegiatan yang ada di masyarakat sesuai dengan hasil identifikasi, mengedukasi para wirausaha sesuai dengan hasil identifikasi yang sebelumnya sudah dilakukan. Pada kegiatan KKN KWU ini, tahap implementasi dilakukan 
dengan mengadakan lokakarya untuk mengembangkan potensi masyarakat dalam bentuk seminar edukatif. Lokakarya dan Pelatihan Kewirausahaan dilakukan pada hari Senin, 27 Januari 2020 di Aula Kantor Kepala Desa pada pukul 09.00-12.00 WIB. Lokakarya tersebut meliputi kegiatan pembukaan lokakarya dan beberapa sesi materi yang dibawakan oleh tim KKN KWU Unpad, yaitu dosen dan mahasiswa dari berbagai disiplin ilmu.

\section{HASIL DAN PEMBAHASAN}

\section{Hasil Pelaksanaan Lokakarya}

Lokakarya dan Pelatihan Kewirausahaan yang dilaksanakan oleh tim KKN KWU Unpad dilaksanakan dengan melibatkan beberapa elemen masyarakat, seperti para wirausahawan, taruna karya, organisasi pemuda dan para perangkat desa dalam pemberdayaan desain kemasan produk. Lokakarya ini dilaksanakan pada tanggal 27 Januari 2020 dan meliputi kegiatan pembukaan lokakarya, sesi materi pertama yang dibawakan oleh Dosen Universitas Padjadjaran, dan sesi materi kedua yang dibawakan oleh mahasiswa dari berbagai disiplin ilmu (Gambar 4).

Sesi materi pertama merupakan sesi pematerian yang dibawakan oleh dosen Unpad. Sesi ini diawali dengan mengangkat bahasan utama KKN ini, yaitu tentang desain kemasan produk. Judul yang diangkat adalah "Pemberdayaan Masyarakat dengan Meningkatkan Berpikir Kreatif dalam Inovasi Desain Produk Hasil Olahan Desa Pamulihan Agar Lebih Digemari Masyarakat Luas"disampaikan oleh tim Dosen Unpad. Selanjutnya merupakan pemberian materi bertema "Pemberdayaan Media Digital dalam Pemasaran Produk". Program seminar ini diharapkan dapat menyiapkan masyarakat pelaku usaha untuk mendalami wawasan dan memperluas pandangan masyarakat pelaku usaha mengenai pemasaran dalam dunia digital.

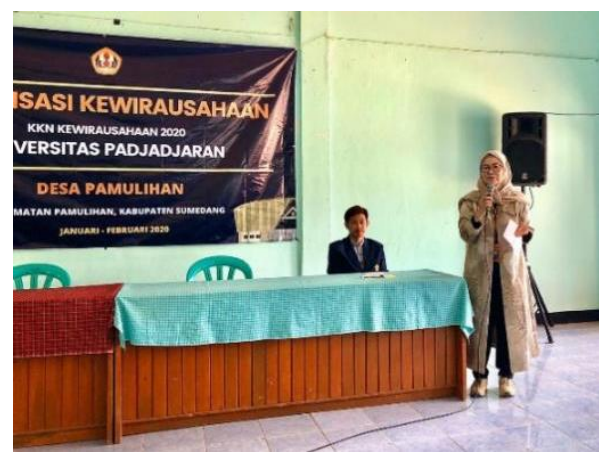

(a)

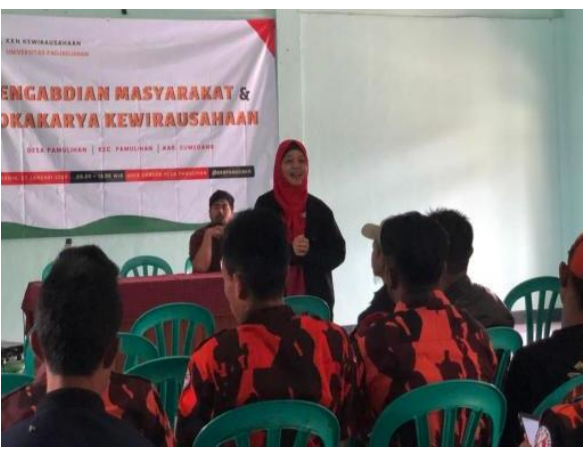

(b)

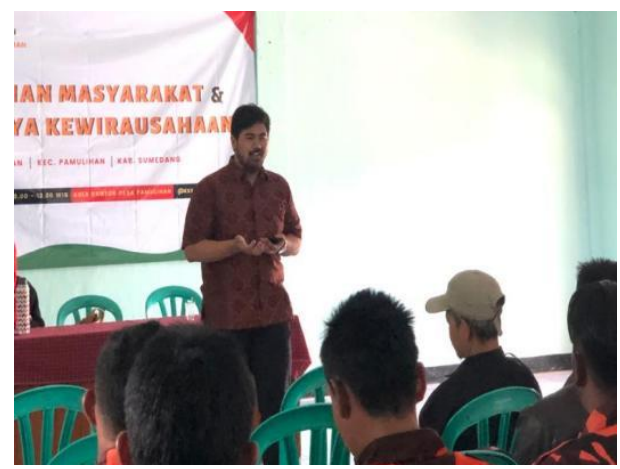

(c)

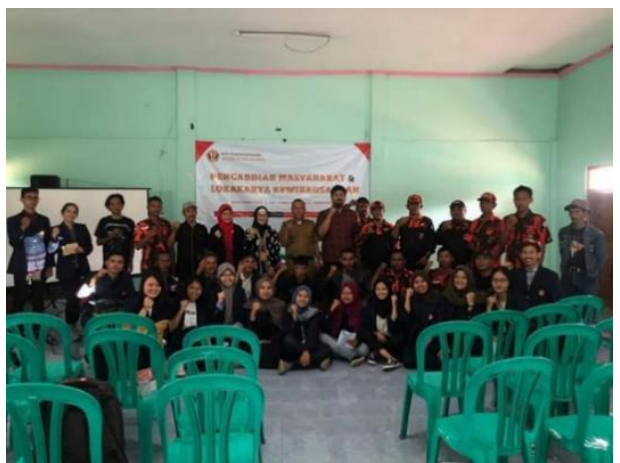

(d)

Gambar 4. Pelaksanaan Lokakarya dan

Pelatihan Kewirausahaan, meliputi (a) pembukaan, (b) sesi materi pertama, (c) sesi materi kedua, dan (d) foto bersama

(Sumber: Dokumentasi Pribadi, 2020) 
Sesi materi kedua dibawakan oleh mahasiswa tim KKN KWU Unpad yang mengangkat tema "Motivasi Kewirausahaan Berkelanjutan". Isi pematerian adalah mengenai motivasi untuk tetap berinovasi dan berkreasi dalam berwirausaha agar dapat mengikuti perkembangan zaman. Selanjutnya, mahasiswa memberikan materi tentang "Menentukan Harga Pokok Produk". Isi materi adalah panduan untuk membantu wirausahawan menentukan harga jual produk dan mengetahui seberapa besar laba yang didapat dari harga jual produk tersebut. Terakhir, mahasiswa menyampaikan materi tentang strategi marketing menggunakan media sosial, dengan judul "Peran Media Sosial dalam Pemasaran Produk". Materi ini penting diberikan karena menurut Susanti, dkk (2019), potensi pasar digital di Indonesia yang besar, dibuktikan dengan banyaknya masyarakat di Indonesia yang mengakses dan memanfaatkan beragam media sosial termasuk untuk memasarkan produk usaha.

\section{Pembahasan}

Pada KKN KWU Unpad tahun 2020 ini telah dilaksanakan Lokakarya dengan tujuan untuk meningkatkan pola berpikir kreatif masyarakat Desa Pamulihan. Tujuan ini ditetapkan berdasarkan analisis kebutuhan yang telah dilakukan oleh tim KKN KWU Unpad yang menemukan bahwa Desa Pamulihan memiliki banyak potensi sampai menjadi desa yang swadaya, tetapi potensi ini perlu diiringi dengan pola pikir yang inovatif dan kreatif agar mampu memasarkan produknya lebih luas.

Melalui lokakarya ini, beberapa tema tentang kewirausahaan telah disampaikan kepada masyarakat Desa Pamulihan. Materi yang disampaikan utamanya adalah mengenai desain kemasan yang inovatif, tetapi materi lainnya turut disertakan agar dapat memantik pola pikir inovatif peserta lokakarya.

Kegiatan ini menghasilkan umpan balik kualitatif dari peserta yang apabila disimpulkan meliputi beberapa poin. Pertama, masyarakat Desa Pamulihan ingin dibantu terutama dalam hal pengemasan produk. Selain itu, masyarakat Desa Pamulihan ingin dibantu terkait strategi pemasaran produk, sehingga produknya dapat menarik para investor untuk menanamkan modalnya dan lebih dikenal masyarakat luas, yang pada akhirnya berpeluang untuk meningkatkan pendapatan.

Untuk meningkatkan luaran kegiatan pengabdian masyarakat terutama dalam program KKN KWU Unpad, penulis memberikan beberapa saran. Pertama, program KKN KWU pada tahun-tahun selanjutnya dapat melanjutkan tema lokakarya ini yaitu memberikan pelatihan skill untuk membuat kemasan produk. Kedua, peserta lokakarya pada KKN KWU selanjutnya dapat ditingkatkan sehingga manfaatnya bisa dirasakan oleh lebih banyak pihak. Terakhir, lokasi, waktu, dan peralatan penunjang lokakarya harus dipersiapkan dengan lebih matang. Saran ini diajukan berdasarkan pengalaman penulis di mana sempat terjadi pemadaman listrik yang menjadikan penyampaian materi sedikit terhambat.

\section{SIMPULAN}

Desa Pamulihan merupakan desa yang memiliki berbagai potensi di bidang kewirausahaan, tetapi potensi ini perlu disertai dengan inovasi dan kreativitas. Pada tahun 2020, KKN Kewirausahaan Unpad berusaha untuk memantik inovasi dan kreativitas masyarakat Desa Pamulihan untuk meningkatkan potensinya tersebut.

Kegiatan KKN ini diawali dengan familiarisasi dan survei kebutuhan masyarakat hingga tim KKN memperoleh gambaran permasalahan yang berkaitan dengan keberlangsungan wirausaha di Desa Pamulihan. Permasalahan yang ditemui antara lain adalah kurangnya inovasi dan kreativitas dalam pemasaran produk, misalnya bagaimana mengemas produk dan memasarkannya, pemasaran produk digital, serta kurangnya inisiatif yang tinggi dari masyarakat muda Desa Pamulihan.

Untuk mengatasi permasalahan tersebut, dilaksanakanlah kegiatan lokakarya dan pelatihan kewirausahaan dengan tujuan meningkatkan meningkatkan pola berpikir 
kreatif masyarakat Desa Pamulihan agar produk yang dihasilkan dapat dipasarkan secara lebih luas. Lokakarya ini dilaksanakan dengan berbagai sesi pematerian, yaitu tentang bahasan utama desain kemasan produk yang kreatif, pemasaran produk digital, kewirausahaan yang berkelanjutan, penentuan harga pokok produk, dan pemasaran menggunakan media sosial. Diharapkan program lokakarya dan pelatihan kewirausahaan untuk masyarakat Desa Pamulihan ini dapat lebih mengembangkan usaha dengan variasi yang lebih kreatif, kemasan yang lebih menarik dan teknik pemasaran digital melalui berbagai media massa, juga menambah sumber penghasilan masyarakat bahkan menarik investor untuk membantu pemodalan usaha mereka.

\section{UCAPAN TERIMAKASIH}

Penulis berterima kasih banyak kepada pihak Universitas Padjadjaran yang telah memberikan skema pendanaan untuk pelaksanaan pengabdian masyarakat ini. Penulis juga berterima kasih kepada Kepala Desa Pamulihan yang telah memberikan kesempatan bagi mahasiswa Unpad untuk mengaplikasikan program KKN-nya.

\section{DAFTAR PUSTAKA}

Badan Pusat Statistik Sumedang. (2019). Kecamatan Pamulihan dalam Angka 2019. Diakses dari https://sumedangkab.bps.go.id/publicati on/2019/09/26/3c6d3991fdec8bf7dc7e4 289/kecamatan-pamulihan-dalamangka-2019.html

Heizer, J. \& Render, B. (2014). Operations Management (11th Ed.). Pearson.

Hiliana, Kirana, D. H., \& Rejito, C. (2020). Pemberdayaan Masyarakat dalam Upaya untuk Meningkatkan Taraf Kehidupan melalui Inovasi Produk Bebas Bahan Kimia Berbahaya di Desa Pamulihan Kabupaten Sumedang. Kumawula, 3(2), 358-366.

https://doi.org/10.24198/kumawula.v3i2
Hurley, R \& Hult, G.T.M. (1998). Innovation, Market Orientation, and Organizational Learning: An Integration and Empirical Examination. Journal of Marketing, 62(3). http://doi.org/10.2307/1251742

Karlina, N., Halim, H.A., Azizi, M. F., Athusholihah, A. \& Tarliyah, A. (2019). Pemberdayaan Jiwa Kewirausahaan Masyarakat Desa Cisempur Dan Pendampingan Kewirausahaan Berbasis Ecommerce. Kumawula, 2(3), 262-269. http://doi.org/10.24198/kumawula.v1i3. 24592

Kotler, K. (2011). Marketing Management (14th Ed). Pearson. ISBN-10: 0132102927, ISBN-13: 9780132102926 .

Maulana, A. (2020). KKN Tematik Kewirausahaan Unpad, Wujud Kebijakan Kampus Merdeka. Universitas Padjadjaran. Diakses dari https://www.unpad.ac.id/2020/03/kkntematik-kewirausahaan-unpad-wujudkebijakan-kampus-merdeka/

Purnomo, B \& Purnomo, B.R. (2017). Pengembangan Produk dan Inovasi Produk Pada Teh Hijau Cap Pohon Kurma (Studi Pada Pt Panguji Luhur Utama). Jurnal Maksipreneur, 6(2), 2735.

http://dx.doi.org/10.30588/jmp.v6i2.300

Rogers, E.M., (2010). Diffusion of Innovations (4th Ed). Simon and Schuster.

Stamm, B.V. (2008). Managing Innovation, Design and Creativity. John Wiley \& Sons.

Sugiyono. (2010). Metode Penelitian Kuantitatif Kualitatif dan $R \& D$. Bandung: Alfabeta.

Susanti, S., Gunawan, W., \& Sukaesih, S. (2019). Pengembangan Pemasaran Bordir Dan Kelom Geulis Tasikmalaya Melalui Media Sosial. Kumawula, 2(3), 248-261. http:// doi.org/10.24198/kumawula.v1i3.25256 
Trott, P. (2009). Innovation Management and New Product Development. Article in $R \& D \quad$ Management. https://doi.org/10.1111/j.14679310.2009.00551_1.x

White, M.A. \& Bruton, G.D. (2010). The Management of Technology and Innovation: A Strategic Approach. Oklahoma: Thomson South-Western. 